\title{
Thermal impact of the environment on the cables supplying electronic fire fighting devices
}

Bogdan Perka, Marek Suproniuk, Karol Piwowarski

Bogdan Perka, Marek Suproniuk M.D., Karol Piwowarski M.D., "Thermal impact of the environment on the cables supplying electronic fire fighting devices," Proc. SPIE 11442, Radioelectronic Systems Conference 2019, 114421D (11 February 2020); doi: 10.1117/12.2565128 


\title{
Thermal impact of the environment on the cables supplying electronic fire fighting devices
}

\author{
Bogdan Perka $^{* a}$, Marek Suproniuk ${ }^{\mathrm{a}}$, Karol Piwowarski ${ }^{\mathrm{a}}$ \\ ${ }^{a}$ Military Academy of Technology, Faculty of Electronic, Warsaw, Poland.
}

\begin{abstract}
The article discusses a phenomenon of heat exchange between the environment and an electrical cable in temperature conditions exceeding the permissible values for commonly used non-flammable electrical cables. The method applying the thermal diffusivity coefficient of electrical cable structural elements was used for the model, which constitutes own research contribution of the author into studying the thermal phenomena in electrical cables. The correctness of the results generated by the developed temperature model was verified based on the experimental data obtained from an individually designed and constructed test stand. Comparing the proposed solution with experimental data has proven its usefulness for the adopted modelling purpose.
\end{abstract}

Keywords: fire temperature, temperature model, safety, fire-fighting systems, electrical wiring, heating.

\section{INTRODUCTION}

Ensuring the safety of people, equipment and buildings with a risk resulting from a fire event depends on the correct operation of systems supporting such safety. The implementation of this task requires ensuring complete supply and controls of the systems and equipment, which should operate in the event of the appearance of technical conditions during a fire $\left(200{ }^{\circ} \mathrm{C} \div 1200{ }^{\circ} \mathrm{C}\right)$ [2]. Heating of power cables for fire-fighting equipment disturbs or even prevents their correct operation or control [11]. Such equipment includes, among others: emergency and rescue lighting, fire pump electric motors and fans, sound warning systems, guaranteed power supply sources (batteries, power generators). The correct operation of the entire fire-fighting system largely depends on the knowledge regarding the physical condition of the supply cable system. In order to determine this condition, it is necessary to develop an electric cable behaviour model within a fire thermal environment. The currently applied temperature model assumes a cable divided into two zones: hot and cold, and the cable functionality assessment depends on the percentage share of the hot zone in the total cable length [2]. This model assumes that the heating of the cable is concentrated only within the hot zone (or at one point of the zone), with the cable remaining within normal operating conditions outside of this zone $\left(-40{ }^{\circ} \mathrm{C} \div 90{ }^{\circ} \mathrm{C}\right)$ [2], [12], [15]. Moreover, it is assumed that the effect of temperature disturbance in the hot zone of the cable (or at one point of the zone) is immediately experienced in all other points of the cable. This model satisfies the requirements of a typical thermal system with lumped parameters. Such a system does not take into account the presence of an intermediate zone, in which the conductors can have a higher temperature than the one specified as normal. The fact that the effects of a disturbances in one point of the cable will be visible in another point with some delay is omitted.

The model of thermal conductivity in an electric cable discussed by the authors represents a new and original approach to the issue of temperature modelling. It takes into account the fact that the thermal parameters of a cable are distributed uniformly along its length, therefore, there is an intermediate zone between a hot and cold zone. It also enables calculating the cable temperature at any moment in time, in the course of the heating process. The model utilizes a thermal conductivity partial differential equation, with its solution using the operational calculus and Laplace transform. The independent variables in the model are: heating time $t$ and the coordinate of distance $x$ from the heat source. This enabled modelling a continuous conductor temperature waveform during heating, along the cable axis and on this basis determining the transmission capacity of the cable.

In fire thermal conditions, the resistance of conductors in electric cables increase approximately fivefold relative to the resistance of the conductors in normal operating conditions, along the same cable section length. The effect is decreased

*bogdan.perka@wat.edu.pl

Radioelectronic Systems Conference 2019, edited by Piotr Kaniewski, Jan Matuszewski, Proc. of SPIE Vol. 11442, 114421D · () 2020 SPIE · CCC code: 0277-786X/20/\$21 · doi: 10.1117/12.2565128 
supply voltage in the cable which powers fire-fighting devices [4]. An attempt to run, e.g., a fire pump electric motor at the effective voltage $\mathrm{U}_{\mathrm{sk}}$ ' decreased by $10 \%$ induced an increase of the starting current $\mathrm{I}_{\mathrm{r}}$ ' in the stator circuit by $11 \%$ and a decrease of the starting torque $\mathrm{M}_{\mathrm{r}}{ }^{\prime}$ of the motor by $19 \%$ [1], [4]. The starting torque $\mathrm{M}_{\mathrm{r}}{ }^{\prime}$ exceeding the minimum critical value and the starting current Ir increase make the start-up of a pump electric motor difficult or even impossible in the event of overcurrent protection trip.

Determining the thermal condition of electrical cables (active range $S_{\dot{z} p}<10 \mathrm{~mm}^{2}$ ) enables to evaluate the transmission capacity of cables and to formulate the requirement to be met by the system, in order to ensure the functionality of the fire-fighting equipment [11].

Temperature accompanying a fire causes a heat flux flow in copper conductors of power cables. Heating is a phenomenon, which determines the performance and operational durability of the cables. This flow is spontaneous in heterogeneous temperature fields, i.e., with a temperature difference.

The heat flow within an electrical cable has a significant impact on the parameters of fire-fighting system electronic equipment. It induces a change in the parameters of the electronic elements of semi-conductor control and signalling devices [8].

\section{ELECTRICAL CABLE TEMPERATURE MODEL}

\subsection{Electrical cable model temperature}

The temperature of heated copper conductors changes along the axis of the cable, as a result of heat loss to the environment (Fig. 1). The developed model assumes that heat loss in the cable-environment system results from:

a) cable copper conductor electrical insulation heat capacity,

b) thermal radiation from the electrical insulation to the environment,

c) thermal resistance of a cable copper conductor.

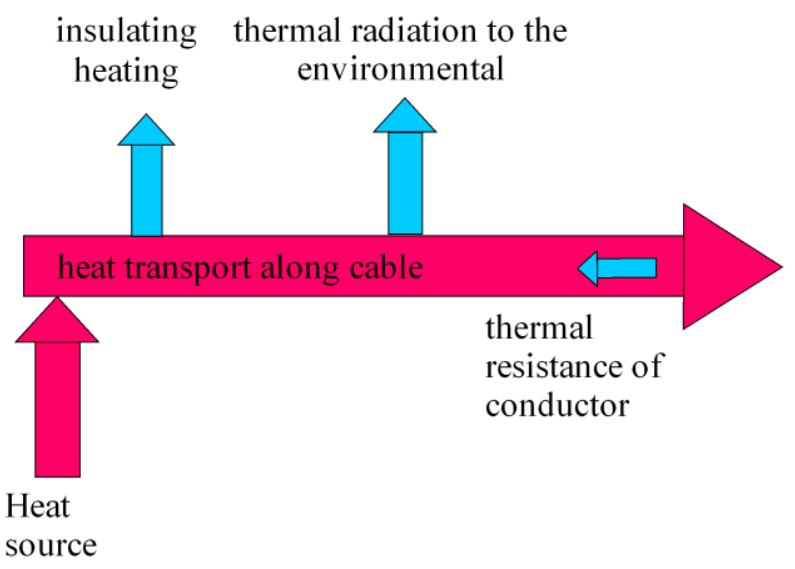

Figure 1. Heat loss structure of the temperature model

The direct cause for a conductor temperature decrease is the penetration of the heat flux from the side surface of the conductor to primary insulation (Teflon, mica) and external insulation (HFFR). Heat penetration from a conductor into the environment is determined by a transverse heat loss, while the heat losses caused by thermal resistance of the conductor are heat transfer losses along the longitudinal axis of a cable. Due to the high thermal conductivity of copper, transverse heat losses dominate compared to longitudinal loss. Transverse loss depends on the side surface of the conductors, materials used for electrical insulation of a cable and the environmental conditions in which the cable is installed. Transport loss (longitudinal) do not depend on the environmental conditions, and their magnitude is proportional to the thermal conductivity coefficient $\lambda$ of the conductor material. 


\subsection{Temperature model design}

The procedure of determining a cable heating model can be divided into two stages: heating and steady state. Conductor temperature change rate depends on the physical conditions of the environment in the form of heat source temperature fields and the remaining space surrounding the cable, as well as thermal parameters of the insulating materials (thermal conductivity, thermal capacity).

The manner of impact of a heat source on the cable may be determined by, e.g., fire curve or as a function of any temperature change waveform (e.g. step).

Equation describing the system has the form of second order partial differential equation [1], [7]:

$$
\nabla^{2} \varphi=k^{2} \cdot \frac{\partial^{2} \varphi}{\partial t^{2}}+k \frac{\partial \varphi}{\partial t}+f(x, t)
$$

where: $k$ - material scale associated with thermal productivity

The equation (1) is also called a thermal conductivity equation or a diffusion equation. The parameter $\varphi$ in the comparison represents the temperature of cable conductors in a homogeneous environment (with constant properties in the set direction). It is also noted in the form:

$$
\nabla^{2} \varphi=k \frac{\partial \varphi}{\partial t}
$$

and

$$
\frac{\partial^{2} T}{\partial x^{2}}=\frac{1}{\alpha} \frac{\partial T}{\partial t}
$$

the Laplace transform, we come to the operator domain. An operator form enables determining the cable conductor temperature $T(x, t)$ as a response to an step function $T_{0}$. For this purpose, a system with distributed parameters is replaced by a system with lumped parameters, described by transmittance $H(x, s)$.

Under the assumption that a function forcing the heat flux flow $T(0, t)$ has the form of $e^{s t}$, the temperature $T(x, t)$, at any point with a coordinate $x$, is defined by a relationship:

$$
T(x, t)=H(s, t) \cdot e^{s t}
$$

By substituting equation (4) to equation (3) we get:

$$
\frac{\partial^{2} H}{\partial x^{2}} \cdot e^{s t}=\frac{s}{\alpha} \cdot H(x, s) \cdot e^{s t}
$$

and

$$
H(x, s)=A e^{\sqrt{\frac{s}{\alpha}} x}+B e^{-\sqrt{\frac{s}{\alpha}} x}
$$

where $A$ and $B$ are constants.

Due to the amplitude-wise finite response value, the constant $A$ in the equation (6) must be equal to 0, otherwise the transmittance $H(x, s)$ would adopt an infinite value at point $x=\infty$, which is impossible due to the rules of physics. For this reason, the equation (6) takes the form: 


$$
T(x, t)=\mathcal{L}^{-1}\left[H(x, s) \frac{T_{0}}{S}\right]=\mathcal{L}^{-1}\left[B e^{-\sqrt{\frac{s}{\alpha}} x} \cdot \frac{T_{0}}{S}\right]
$$

Applying the inverse Laplace transform of the function included in the parentheses, we obtain an equation of a system with distributed parameters, in the form:

$$
T_{\text {erfc }}(x, t)=B \cdot T_{0} \operatorname{erfc}\left(\frac{x}{2 \sqrt{\alpha t}}\right)
$$

where:

$\alpha\left[\mathrm{W} / \mathrm{m}^{2} \mathrm{~K}\right]-$ thermal diffusivity coefficient, material constant

$x[\mathrm{~m}]$ - distance from the heat source,

$t[\mathrm{~s}]$ - elevated temperature impact time,

$T_{0}\left[{ }^{\circ} \mathrm{C}\right]$ - excitation temperature (heat source).

Notation of a cable conductor temperature model described by equation (10) contains a non-elementary supplemented function of the erfc error with parameters $(x, t)$.

A graphical representation of the $\mathrm{T}_{\text {erfc }}(\mathrm{x}, \mathrm{t})$ model equation solution is a temperature curve with an exponential waveform (Fig. 2.) [1], [12].

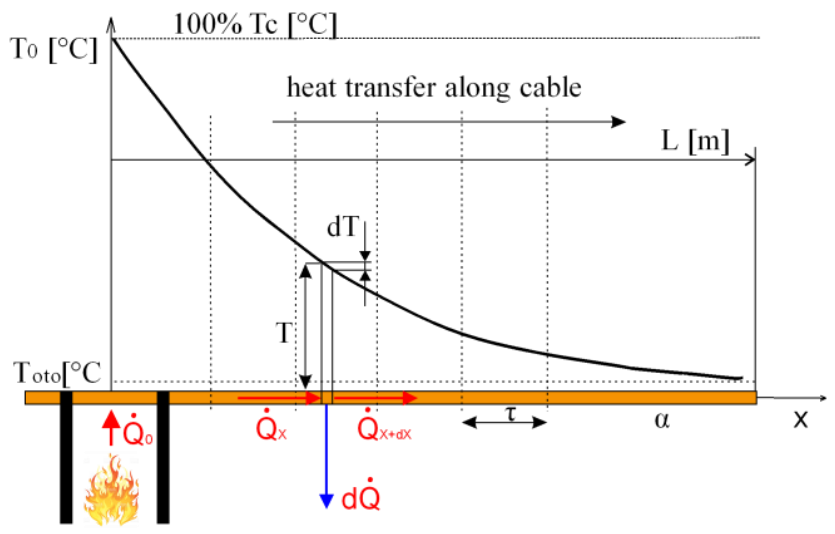

Figure 2. Cooling curve theoretical waveform

One temperature curve can be determined for each time moment.

The impact of a fire temperature field on a cable can be divided into two stages: heating and steady state. The determination of the curve coefficients based on non-linear approximation of the experimental data is approximated more accurately, the more the temperature forcing cable heating is stabilized over time (steady state). Selecting a time constant $\tau_{c}$ value is of significance to the accuracy of a cable thermal model. Therefore, it is important for the results used to validate the model to be taken from a time moment, where the cable conductor temperature response is of a steady character.

Table 1 shows the results of the heating curve time constant $\tau_{o p}$ and delay time $\tau_{c}$ calculations using three different methods, as a response to an step excitation as a result to placing a cable in a heated-up heating chamber. 
Table 1. Summary of heating time parameter calculation of studied cables

\begin{tabular}{|c|c|c|c|}
\hline \multirow{2}{*}{ No. } & \multirow{2}{*}{ Method } & $\begin{array}{c}\text { Time } \\
\text { constant } \boldsymbol{\tau}_{\mathbf{c}}\end{array}$ & Delay time $\boldsymbol{\tau}_{\text {op }}$ \\
\cline { 3 - 4 } & {$[\mathrm{s}]$} & {$[\mathrm{s}]$} \\
\hline 1 & tangent & 401 & 62 \\
\hline 2 & $\begin{array}{c}\text { tangent } \\
\text { and point }\end{array}$ & 165 & 62 \\
\hline 3 & two points & 127.5 & 84.5 \\
\hline
\end{tabular}

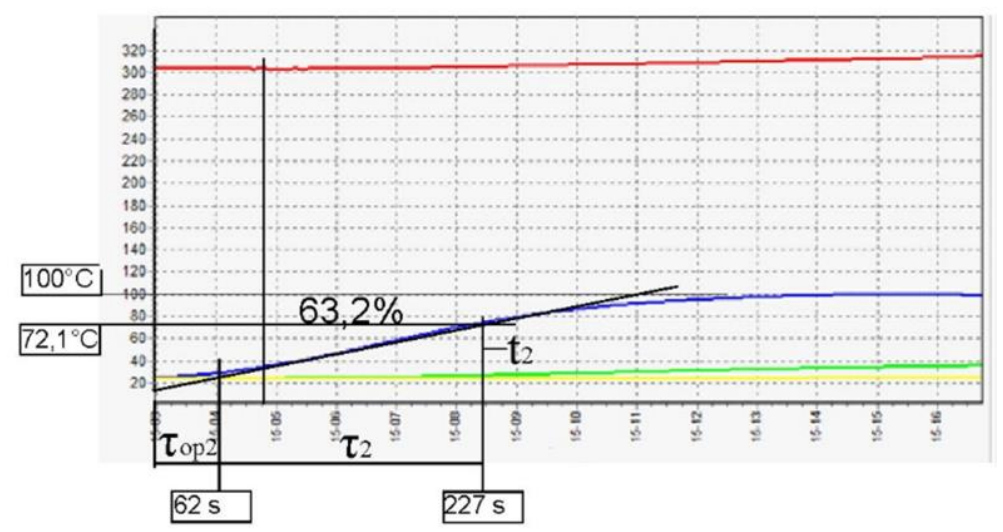

Figure 3. Cooling curve theoretical waveform

An analytical [11] or graphical method (Fig. 3) can be used to determine a time constant. The temperature waveform recorded by the recorder should be used for that purpose. Due to a limited accuracy of tangent plotting, the graphical method is less accurate than the analytical one. It is assumed that a steady state occurs after $3 \div 5$ time constants determined based on the response of a system to an excitation [5]. Cable conductor temperature response for the first thermocouple, counting from the cable outlet from the heating chamber, would reach $63.2 \%$ of the maximum response value after 1622 seconds. Bearing in mind the results obtained through the graphical and analytical methods, we assume that the steady state of the heating process will occur after 1600 seconds from the temperature excitation, with the time constant assumed for the calculations amounting to 400 seconds.

\section{STAND FOR TESTING CABLE HEATING}

A measuring system was constructed in order to verify the proposed model. A calculation system has to be additionally used in certain measuring systems, in order to obtain information about the condition of a given object. An example of such system in an application for testing semi-conductor materials is presented in research papers [9], [10]. The analysis of the electrical cable temperature measurement methods enables to select one, which would enable recording the temperature in the form of an electric signal, suitable for use in further calculations associated with the validation of the electrical cable heating mathematical model. The method utilizing thermo-elements is beneficial owing to the structural possibilities of thermocouple sensors, measurement accuracy and the option to utilize the obtained measurement results in further calculations. The test stand designed and constructed by the authors consists of: a laboratory furnace, a power supply system with adjusted temperature inside the heating chamber, a measuring system with temperature processing and recording, a supporting structure for a tested cable. Stand diagram is shown in figure 4. 


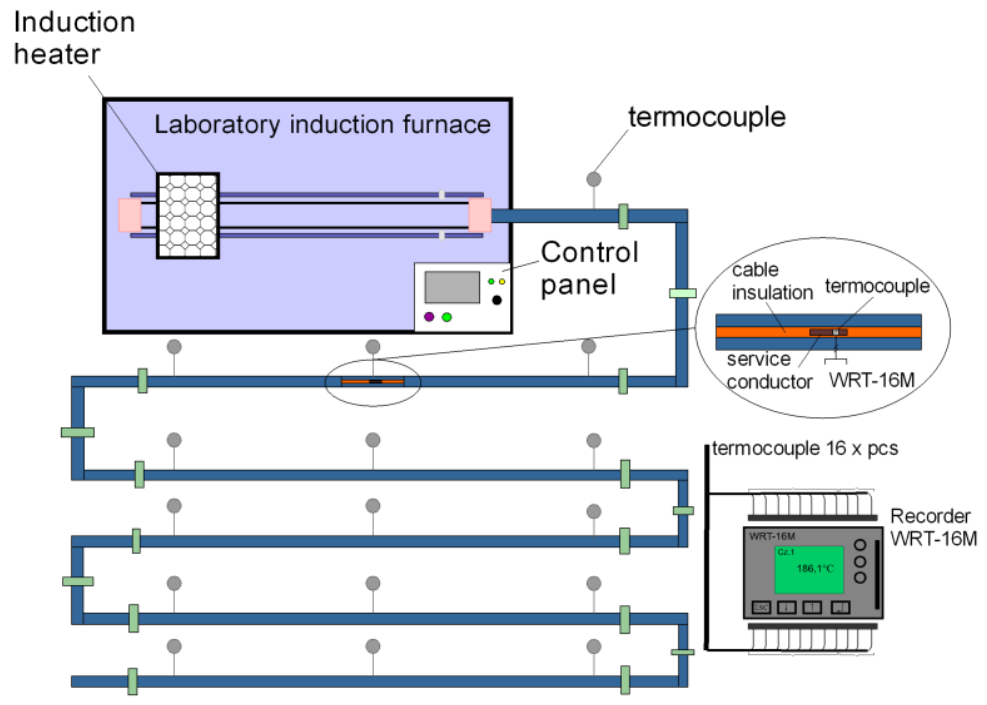

Figure 4. Test stand diagram

The furnace design enables reaching a temperature of approximately $400^{\circ} \mathrm{C}$ inside the heating chamber. The hot zone length was $1.0 \mathrm{~m}$. The cable section with visible temperature changes was selected experimentally. For a cable installed in an open cable tray it amounted to $2.0 \mathrm{~m}$. The tests involved a non-flammable (N)HXH 3x6 mm ${ }^{2}$ FE180 PH90/E90 cable, with CU ETP CW004 copper conductors, with copper content of 99.8\%, which enables an assumption that the copper is pure in terms of material [3], [12].

Measurements from thirteen thermocouples placed every $0.15 \mathrm{~cm}$ along the cable, were recorded in a WRT-16M recorder via a RS236/USB interface and saved in a computer. The temperature recording time was $120 \mathrm{~min}$, which corresponds to the technical requirements for electrical systems powering fire-fighting equipment [14], [15], [16]. After entering into a computer algorithm, the measurement data were substituted into a mathematical model, and the calculation results shown in the form of a graph.

\section{CALCULATION RESULTS FOR THE PRESENTED MODEL}

A result of a numerical simulation of the $\operatorname{Terfc}(\mathrm{x}, \mathrm{t})$ model is a family of exponential curves. Each curve represents a calculation result of conductor temperature changes along the cable within a single time moment, elapsed since the temperature excitation trip. The curves shown in figure 5 are derived from theoretical calculations not taking into account the measurement data, and are only a model simulation of the temperature waveform. The curves flatten over the heating time, which is a result of gradual setting of the temperature throughout the cable. 


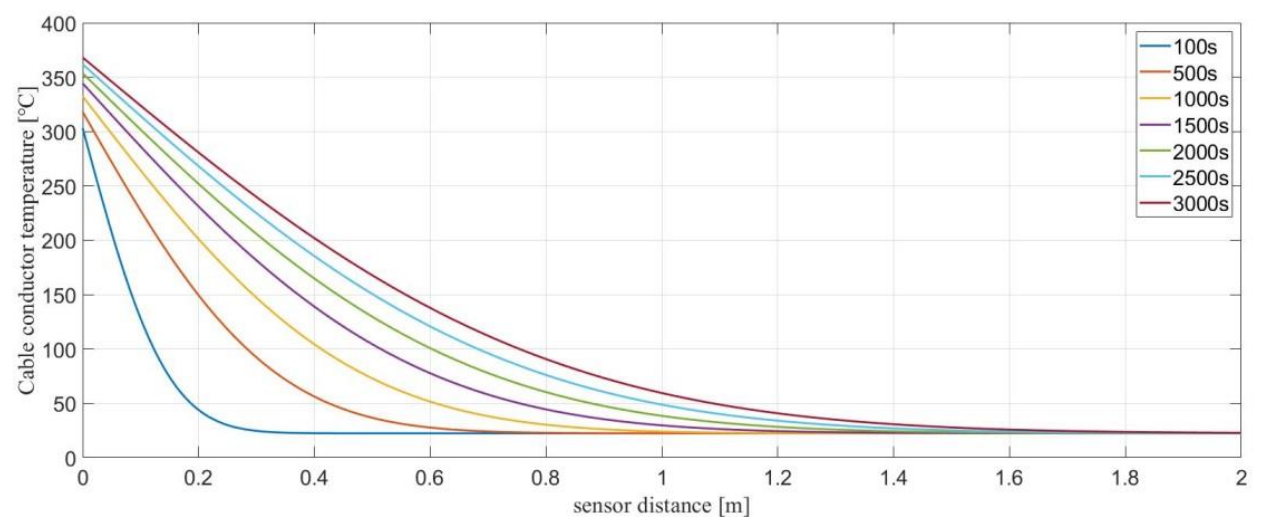

Figure 5. Model numerical simulation result.

Inputting the measurement data into the model calculation algorithm makes the model approximate the model result to the experimental result of the temperature waveform. The model utilizes the classical method of least squares based on the Levenberg - Marquadt (algorithm L-M) algorithm to approximate the data [6], [13], [17]. The result of temperature calculations and approximation for any time moment equal to $2000 \mathrm{~s}$ from the temperature excitation trip is shown in figure $6 \mathrm{a}$.
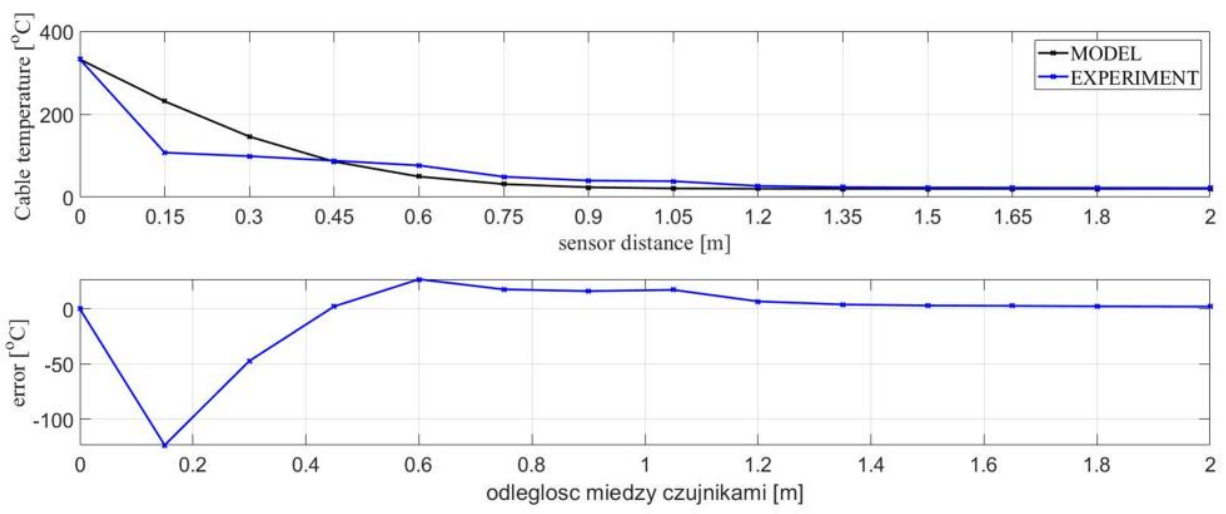

Figure 6. The model approximation and calculation result: a) measurement data approximation; b) comparison of modelling results and experimental data.

Using model calculation algorithm, we are able to determine the damping parameters of the temperature exponential curve within a studied power cable.

$$
T_{(x, t=2000 s)}\left[{ }^{\circ} \mathrm{C}\right]=\mathrm{a} \cdot e^{-b x}
$$

The result of the calculations for a selected time moment of 2000 seconds are coefficients $a$ and $b$, which amount to: a= 
$328.3\left[{ }^{\circ} \mathrm{C}\right], \mathrm{b}=4.637[-]$, respectively.

Parameter $a$ is an instantaneous value of the forcing temperature. Whereas parameter $b$ determines the slope of the temperature curve, which corresponds to the cable cooling rate. In the physical dimension, it represents the thermal diffusivity coefficient $\alpha$ of a conductor and electric insulation, as an entire thermal system.

Increased coefficient $\alpha$ results in faster cooling of the cable. The value of coefficient $\alpha$ calculated by the algorithm is a resultant value for several insulation layers comprising the cable.

Figure $6 \mathrm{~b}$ shows the difference between the temperature value calculated by the model and the temperature measured during the experiment. The data approximation method used in the model provides satisfactory results thanks to fast convergences and easy implementation of the data in the model. The difference between the value calculated by the model relative to the experimental data is the biggest in the area of the cable closest to the heat source. This area exhibits the highest temperature increments, which is not beneficial for the model calculation algorithm, although, as the distance coordinate $x$ increases, the algorithm generates results with an increasing accuracy.

\section{CONCLUSIONS}

The method for determining the temperature of electrical cable conductors discussed in the articles represents a new approach towards the determination of electrical cable heating in temperature conditions similar to a fire event. Based on the obtained calculation results, it is possible to determine the resistance of electrical cables, depending on the time of exposure to elevated ambient temperature and the distance from a heat source. This has a huge impact on the conditions of powering electrical equipment, especially the ones responsible for the safety of people and devices in the event of such dangerous phenomena as building fires. The moment of tripping of fire-fighting equipment has a large impact on the reliability of operation of the entire building protection system. The discussed temperature modelling method significantly helps the evaluation of the temperature condition of a cable system powering fire-fighting equipment. This method is a good tool for supporting designers of fire-fighting systems. Extending the hot zone results in a proportional growth of the transition zone. The scaling factors will be developed by the authors in the course of further research. The authors will try to expand the application range of the method onto other structural ways of laying cables than the system of open cable trays.

\section{REFERENCES}

[1] S. Zocholl, “A thermal models in power system protection”, Proceedings of the 26th Western Protective Relay Conferece, Spokane, WA 26-28 October 1999.

[2] J. Wiatr and M. Orzechowski, "Instalacje elektryczne do zasilania urządzeń elektrycznych, których funkcjonowanie jest niezbędne w czasie pożaru", [Electrical systems for powering electrical equipment, required to operate in the event of a fire], Wydanie I, Warszawa 2016.

[3] G. Bontempi and A. Vaccaro and D. Villacci, "Power cables thermal protection by interval simulation of imprecise systems", 2004 IEE Proc. Generat. Transm. Distrib.

[4] Z. Hanzelka, "Jakość dostawy energii elektrycznej, zaburzenia wartości skutecznej napięcia”, [Electricity supply quality, effective voltage value disturbance]. Wydawnictwo Akademii Górniczo - Hutniczej, Kraków 2013.

[5] J. Kisilowski, "Podstawy technik pomiarowych", [Basics of measurement techniques]. OBSERWACJE Wydawnictwo Naukowe, 2005.

[6] S. Osowski and A. Cichocki and K. Siwek, "MATLAB w zastosowaniu do obliczeń obwodowych i przetwarzania sygnałów", [MATLAB used for circuit calculations and signal processing]. Oficyna Wydawnicza Politechniki Warszawskiej, 2006.

[7] T. Zaiczek and O. Enge - Rosenblatt, "Import of distributed parameter models into lumped parameter model libraries for the example of linearly deformable solid bodies, 3-rd International Workshop on Equation - Based Object - Oriented Languages and Tools", October, 2010, Oslo, Norway. 
[8] M. Suproniuk and P. Kamiński and R. Kozłowski and M. Pawłowski, "Effect of deep-level defects on transient photoconductivity of semi-insulating 4H-SiC", Acta Physica Polonica A, vol. 125, pp. 1042 - 1048, 2014,

[9] M. Suproniuk and P. Kamiński and M. Pawłowski and R. Kozłowski and M. K. Pawłowski, "An intelligent measurement system for characterisation of defect centres in semi-insulating materials", Przegląd Elektrotechniczny, vol. 86, pp. 247 -252, 2010,

[10] M. Suproniuk and P. Kamiński nad M. Miczuga and M. Pawłowski and C. Longeaud and J. Kleider, "An intelligent measurement system for diagnosing of semi-insulating materials by photoinduced transient spectroscopy”, Przegląd Elektrotechniczny, vol. 86, pp. 93 - 98, 2009,

[11]Z. Skibko, "Wpływ temperatury granicznej dopuszczalnej długotrwale i temperatury otoczenia na obciążalność prądową długotrwałą przewodów", [The impact of long-term permissible limit temperature and ambient temperature on long-term ampacity of cables]. Wiadomości Elektrotechniczne Vol. 10/2009.

[12] G. Angers, "Rating of Electric Power Cables in Unfavorable Thermal Environmental", New York 2005 IEEE Press Series on Power Engineering.

[13] M. Pawlowski and M. Suproniuk, "The effect of model adequacy error of the correlation method for studies of defect centres by photoinduced transient spectroscopy", Przeląd Elektrotechniczny, vol. 87(10), 2011, pp. 230235

[14] Standard N SEP E-005, "Dobór przewodów elektrycznych do zasilania urządzeń przeciwpożarowych których funkcjonowanie jest niezbędne w czasie pożaru", [Selection of power cables for fire-fighting equipment, required to operate in the event of a fire].

[15] Catalogue of cable manufacturer TF Kable (edition IX 2009).

[16] M. Suproniuk, P. Kamiński, P. Pawłowski, M., and Kozłowski, R., "Baza wiedzy w inteligentnym systemie pomiarowym do badania centrów defektowych w półprzewodnikowych materiałach półizolujących", Przegląd Elektrotechniczny. 86, 247-252 (2010)

[17] Suproniuk M., and Pawłowski M., "The effect of model adequacy error of the correlation method for studies of defect centres by photoinduced transient spectroscopy”, Przegląd Elektrotechniczny. 87. 230-235 (2011) 